\title{
Anlam ve Değer Açısından Kur'an'da Hızır-Mûsâ Kıssasında Çocuğun Öldürülme Meselesi
}

\section{The Issue of Killing of the Child in the Story of Khidr and Moses from the Meaning and Value Perspective}

\section{Bayram Demircigil*}

Dr. Öğr. Üyesi, Sakarya Üniversitesi, İlahiyat Fakültesi, Tefsir Anabilim Dal Assist. Prof, Sakarya University, Faculty of Theology, Department of Tafsir bdemircigil@sakarya.edu.tr | https://orcid.org/0000-0001-5614-8141 Sakarya / Turkey

*Sorumlu Yazar / Corresponding Author

\section{Soner Aksoy}

Arș. Gör., Sakarya Üniversitesi, İlahiyat Fakültesi, Tefsir Anabilim Dalı

Research Assist., Sakarya University, Faculty of Theology, Department of Tafsir

Sakarya / Turkey

snraksoytrbzn@hotmail.com | https://orcid.org/0000-0003-3178-7937

Article Type / Makale Tipi

Research Article / Araştırma Makalesi

DOI: $10.33420 /$ marife. 903003
Article Information / Makale Bilgisi

Received / Gelis Tarihi: 25.03.2021

Accepted / Kabul Tarihi: 20.05.2021

Published / Yayın Tarihi: 30.06.2021

Cite as / Atıf: Demircigil, Bayram; Aksoy, Soner. “Anlam ve Değer Açısından Kur'an'da Hızır-Mûsâ Kıssasında Çocuğun Öldürülme Meselesi”. Marife 21/1 (2021), 231-252. https://doi.org/10.33420/marife.903003

Plagiarism / Intihal: This article has been reviewed by at least two referees and scanned via a plagiarism software. / Bu makale, en az iki hakem tarafından incelendi ve intihal içermediği teyit edildi.

Copyright / Telif Hakkl: "This article is an open access article distributed under the terms and conditions of the Creative Commons Attribution-NonCommercial-NoDerivatives 4.0 (CC BY-NC-ND 4.0) International License." / "Bu makale Creative Commons Alıntı-GayriTicari-Türetilemez 4.0 (CC BY-NCND 4.0) Uluslar arası Lisansı altında lisanslanmıştır." 


\section{Anlam ve Değer Açısından Kur'an'da Hızır-Mûsâ Kıssasında Çocuğun Öldürülme Meselesi}

Özet

Kur'an'da yer alan ilginç ve üzerinde pek çok tartışmanın cereyan ettiği anlatılardan biri hiç kuşkusuz Kehf sûresi 60-82. ayetleri arasında geçen Hızır-Mûsâ kıssasıdır. Bu kıssada çocuğun öldürülme meselesi İslam ilim geleneğinde en çok konuşulan konular arasında bulunup adalet idesi açısından bazı eleștiri ve değerlendirmelere zemin olușturmuştur. Bu meseleyle alakalı konular İslam tarihinin erken dönemi boyunca Eș'arîlik, Mu'tezile ve Mâtüridîlik gibi kelam ekollerince tartıssılan hususlar arasında olmuştur. Buradaki asıl sorun yüce Allah'ın, fiillerinde insandaki adalet tasavvuru ve algısını dikkate alıp almadiğı ve eylemlerini buna uygun olarak sergileyip sergilemediği meselesidir. Konunun modern zihinlerde bir yere oturtulmasının ve gereğince kavranmasının kolay olmadığını kabul etmek gerekir. Kelâm ekolleri bu soruna, ya Allah'ı irade ve kudreti veya adaleti ya da hikmet ve adalet dengesi açılarından yaklaşarak izah getirme çabası sergilemişsler ve tartışmalarıı bu ilkeler ışığında yürütmeye çalışmışlardır. Yine bu mevzu gerek klasik, gerekse modern tefsirlerde çeşitli yönlerden ele alınmaya ve çözümlenmeye çalışılmıştır. Bu tür açıklamalarda, istisnalar bir tarafa bırakılacak olursa meselenin ilahî takdire ve gayb âlemine ilişkin boyutuyla hukûkî/șerî̀ boyutunun genellikle birlikte ve iç içe işlendiği, bu durumun da konuyu anlaşılır kılmaktan ziyade daha karmaşık hâle getirdiği müşahede edilmiştir. Bu nedenle olsa gerek, klasik müfessirler bu hususta daha çok, öldürülen çocuğun yaşı ile öldürülme sebebi üzerinde yoğunlaşmışlardır. Bu yaklaşım biçimi de tarih boyunca çeşitli tartışmalara ve farklı düşüncelerin ortaya konulmasına neden olan bu sorunu anlaşıllır kılmaktan ziyade daha karmaşık hâle getirmiş ve bazı soru işaretlerinin artmasına neden olmuştur. Allah'ın kulları ve kâinat üzerinde uygulamaya koyduğu tasarruflarının beșeri tasavvur ve anlayışa göre şekillenen hukûkî bir çerçevenin esas alınarak sınırlandırılmaya çalışılması isâbetli ve makul bir yaklaşım olarak görülemez. Çünkü varlık âlemindeki her şeyin mutlak hâkimi olan ve her şeyin bilgisini elinde tutan Allah'n fiilleri mutlak hakikatin ifadesidir. Bu konudaki aksi tutum Allah'a eksiklik izafe etmek anlamina gelebilir. Bu noktada Allah'in bazı fiillerinin ardında yatan sebeplerin gerçek anlamda ne zaman bilinip anlaşılacağının belli olmayışının iyice kavranması hayati bir önem taşımaktadır. Nitekim bu gerçek, Kur'an'da pekçok kez vurgulanmıştır.

Hâl böyle olmakla birlikte kimilerince kıssada çocuğun öldürülmesinin insanda var olan adalet duygusunu zedeleyeceği ve Allah'ın mutlak adaletini gölgeleyeceği iddiası ortaya atılmıştır. Bu yaklaşıma göre Allah belirlenmemiş kader gereği insanla ahlakî ilkeler doğrultusunda ilişkide bulunur. Buna karșin söz konusu iddiada Hz. İbrâhîm kıssasında yer aldığı üzere Allah'ın ona çocuğunu kesmesini emretmesi bir problem olarak görülmemiştir. Bu bakış açısı, ilgili olayın Allah insan ilişkisi kapsamında ele alınamayacağı șeklinde gerekçelendirilmiştir. Ne var ki bu görüşün gerçeği yansıttı̆̆ını söylemek oldukça zordur. Zira bu kıssadan da Allah-insan ilişkisine dair bazı ders niteliği taşıyan mesajların çıkarılması pekâlâ mümkündür. Öte yandan böyle bir yaklaşımın benimsenmesinin arka planında meselenin kelamî bir tartışmanın parçası hâline getirilmek suretiyle çocuğun öldürülme meselesi üzerinde aşırı odaklanılmasının yattığını söyleyebiliriz. Sonuçta bu yaklaşımda bir bütün olarak kıssanın anlaşılmasına yardımcı olacak önemli bazı ayrıntılar göz ardı edilmiștir. Diğer taraftan, kıssadaki bu meseleyi anlamada anahtar rolü oynayacak ifadenin Hızır'la Mûsâ buluştuklarında Hızır'ın "Sen asla benimle beraberliğe sabredemeyeceksin. Hakkında bilgi sahibi olmadığın bir șeye nasıl sabredesin ki?" ve ayrılmadan önce "Ben bunu kendi irademle yapmadım" şeklindeki sözleri olduğunu özellikle belirtmemiz gerekir. Böylece bu ifadeleriyle Hızır, Mûsâ'nın beșer aklını aşan birtakım olaylarla karşılaşacağını ve tüm bunların Allah'ın iradesiyle gerçekleşeceğini bulușmalarının en başında dile getirmiş olmaktadır. Kıssadaki bu temel mesaj, bu konuda bütüncül yaklaşımdan uzaklaşılarak gözden kaçırılmışıtır. Bu durumda, kıssanın değerlendirilmesinde ortaya çıkan temel yanılgı, tıpkı Hz. İbrâhîm kıssasıyla ilgili değerlendirmede olduğu gibi Hızır-Mûsâ kıssasında da beșer algısının ötesinde bazı mesajların yer aldığı gerçeğinin dikkate alınmamış olmasıdır.

Yukarıda kaydettiğimiz tüm bu hususlar göz önünde bulundurulmak üzere, biz bütüncül bir bakıșla çocuğun öldürülmesini kıssada kullanılan dilin imkânlarını aşmadan analiz edecek ve Kur'an'da bu kıssanın anlatılmasındaki hedefleri tespit etmeye çalışacağız. Böylece konunun anlaşılmasına bir nebze de olsa katkı sağlamış olacağız. Bu bakımdan makalede, önce âlimlerin konu hakkındaki bakış açıları serdedilmiş, ardından bu hususta geleneksel ve modern yaklaşımlar gözden geçirilmiş ve 
meselenin hukûkî-kelâmî bağlamda ele alınıp alınamayacağı tartışılarak bir sonuca ulaşılmaya çalıșılmıștır. Bu noktada bașlıkta yer alan "anlam" ve "değer" tabirleriyle felsefi bir göndermede bulunmaktan ziyade kıssanın ilgili kısmının içerdiği temel mesajın tespit edilmesi ve bunun muhataplar açısından nasıl bir işleve sahip olduğunun vurgulanması amacı taşıdığımızı belirtmek istiyoruz. Zira konuya felsefî perspektiften yaklaşılması ayrı bir inceleme ve araştırmayı gerekli kılmaktadır. Biz bu çalışmamızda tefsir ilminin sınırlarına bağlı kalmakla birlikte kelamî tartışmaları da göz önünde bulundurduk.

Anahtar Kelimeler: Tefsir, Kur'an, Hızır-Mûsâ, Çocuğun Öldürülmesi, Adalet.

\section{The Issue of Killing of the Child in the Story of Khidr and Moses from the Meaning} and Value Perspective

\section{Summary}

There is no doubt that the child being killed by Khidr in the story of Khidr and Moses in the Qur' ān surah al-Kahf verses 60 to 82 has been one of the most fascinating and controversial issues and brought about some criticism in terms of the sense of justice. The topics related to this issue had been under discussion by kalam schools like Ash'arites, Mu'tazilites, and Maturidites during the early period of Islamic history. The question here is whether Allah considers the human perception of justice in His deeds and acts accordingly. It should be acknowledged that the comprehension of such an issue by modern mindset is not easy. The schools of thought had approached the matter either from the perspective of Allah's will and omnipotence or in the light of justice or concerning the balance between wisdom and justice and made discussions in the light of these concepts. This issue had also been addressed by classical and modern exegetes and analyzed from different perspectives. In these statements, with some exceptions, the aspect related to the predestination and unseen world had been blended with the judicial dimension of the issue. Therefore, they generally concentrated on the age of the child and the grounds for his execution. This attitude has made the issue more complex rather and caused several debates and diverse opinions. It is an inaccurate judgment to limit the actions of Allah on His servants and the universe with a legal framework in line with human perception and understanding because the acts and deeds of Allah who has the sovereignty and knowledge of everything in the universe is the absolute expression of the truth. Thinking otherwise would mean ascribing deficiency to Allah. It is vital to realize that the time of recognition of the reason behind some actions of Allah is quite uncertain for humans. This fact has been emphasized in the Qur' ān numerous times.

Nevertheless, some authors maintained that the murder of the child by Khidr in the story would damage the sense of justice in human and overshadow the absolute justice of Allah. According to them, Allah has relations with humans as undetermined destiny within the boundaries of ethics. Despite this, they never saw the story of Abraham as a problematic matter when Allah ordered him to slaughter his son. They did not consider this case as an example of the relation between Allah and humanity. We should realize that these remarks do not comply with reality because some lessons could also be deduced from this story about the relations between Allah and human. We should acknowledge that the motive behind this approach is to focus excessively on the killing of the child by including this issue in the debates of kalam. As a result, the details which will help to understand the story as a whole have been neglected.

On the otherhand, the key point to understand the matter in the narrative is the sentence used by Khidr when he warned Moses by saying in their meeting "You certainly cannot be patient with me. how can you be patient with what is beyond your knowledge?" and before they depart "I did not do it of my own accord". So, through these remarks, Khidr indicated that Moses would face some incidents beyond human intellect and these would happen by the will of Allah. This essential message in the story was dismissed by some people who did not follow a holistic approach in this matter. Thus, the main misconception in dealing with the story is disregarding the fact that certain messages beyond human comprehension exist in the story of Khidr and Moses as was the case with the story of Abraham.

Given these points, we will be analyzing the subject in a holistic approach without exceeding the limits of the language used in the story and discover the objectives behind the utterance of the story in the Qur' àn. In this paper, we presented the views of scholars, evaluated traditional and modern approaches and, discussed the possibility of analyzing the problem in the context of sharia law and kaläm. At this point, we assert that we aim by the words meaning and value to identify the basic 
message that the related topic includes and its functions for audience rather than referring to the philosophical aspect of the issue because it requires further studies. In this study, we have considered the boundaries of the Qur'ānic exegesis as well as taking kalām discussions into account.

Keywords: Tafsir, Qur'ān, Khidr-Moses, Killing the Child, Justice.

\section{Giriș}

Kur'an kıssalarında yer alan kimi olağandışı/olağanüstü olayların beşerî tasavvura göre adalet ilkesiyle bağdaştırılması mümkün görünmemekte, bunların anlaşılması ve izahında zorluklarla karşılaşılmaktadır. Bu zorluk, ilgili nasların beşerî aklın verileri ve insandaki adalet duygusuyla çözülüp çözülem eyeceğinin imkânıyla ilgili görüş farklılığından kaynaklanmaktadır. Esasen İslam düşünce tarihindeki hüsün-kubuh, salah-aslah ve insanın fiilleriyle ilgili gündeme gelen bir kısım kelâmî tartışmaların da konuyla yakından ilgisi bulunmaktadır. Nitekim bu konular gelenekte Eş'ariyye, Mu'tezile ve Mâtürîdiyye arasındaki tartışmalarda önemli başlıklardandır. Buradaki ana sorun Allah'ın, fiillerinde her zaman beşerî düzeydeki adalet tasavvurunu dikkate alıp almadı̆̆ıdır. Bu soruya Mu'tezile'nin olumlu bir yanıt verdiği ve bu temel yaklaşımın onların düşünce sisteminde önemli bir yer tuttuğu bilinmektedir. Bunun sonucunda onlar, kulları için en yararlı (aslah) olanı yaratmasının Allah hakkında zorunlu olduğunu ileri sürmüşlerdir. Mu'tezile'nin bu sert söylemine karşı Mâtürîdî (ö. 333/944) Allah'ın Hakîm oluşuna vurgu yaparak O'ndan sâdır olan fillerin hikmetin dışına çıkmasının mümkün olmadığını dile getirmiştir. ${ }^{1}$ Buna mukabil, Eş'arilikte Allah'ın getirdiği hükümlerin ve vaz ettiği ilkelerin insan aklı ve tasavvurlarıyla örtüşmesi gibi bir zorunluluk bulunmamaktadır.

Klasik dönemden itibaren konuya yaklaşımla ilgili üç temel bakış açısının hâkim olduğu böylece görülmektedir. Bu çerçevede cereyan eden tartışma, modern zamanlarda Kur'an'da yer alan Hızır-Mûsâ kıssasındaki çocuğun öldürülme meselesiyle yeniden gündeme getirilmiştir. Görünürde haklı bir gerekçe olmaksızın çocuğun öldürülmesinin insandaki akıl ve adalet ilkesiyle bağdaştırılmasında güçlük çekilmektedir. Gelenekte bu konu, Allah'ın adaleti ekseninde genel olarak bir mesele olarak görülmezken bu hususta istisna kabilinden bazı örnekler de yok değildir. Sözgelimi Ebū Ahmed el-Keracî (ö. 360/970 [?]) yaşadı̆̆ı̆ dönemde kimi felsefecilerin "nâkıs ve bozuk akıllarıyla" bu kıssayı vesile ederek Allah'ın adaletini sorgulamaya kalkıştıklarını söylemiştir. ${ }^{2}$ Günümüzde de bir araştırmacı tarafından Kur'an'da anlatıldığı şekliyle çocuğun öldürülmesinin Allah'ın adaletini zedelediğ inin ileri sürüldüğü ve işin içinden çıkılamadığının itiraf edildiği görülmektedir. ${ }^{3}$

Bu durumda vahiy olgusunun temel nitelikleri, Kur'an'ın bütünlüğü ve beşerî dilin imkânları göz önünde bulundurularak bu sorunun ele alınması ihtiyacı hâsıl olmuştur. Dolayısıyla bu araştırmada kelamî tartışmalar da göz önünde bulundu-

${ }^{1}$ Ebū Manșūr el-Mātürīdī, Kitābü't-Tevhīid, thk. Bekir Topaloğlu - Muhammed Aruçi (İstanbul: İrşad Kitabevi, 1422/2001), 191.

${ }^{2}$ Ebū Ahmed el-Keracī, Nüketü'l-Kur'äni'd-dālle 'ale'l-beyān fi envā't'l-ulūm ve'l-aḥkām, thk. İbrāhīm b. Manșūr el-Cüneydil, 4 Cilt (b.y.: Dāru'l-Kayyim, 1424/2003), 2/221.

${ }^{3}$ bk. İlhami Güler, Allah’ın Ahlakiliği Sorunu (Ankara: Ankara Okulu Yayınları, 2019), 105. 
rulmak suretiyle tefsir literatüründen yararlanılarak sorunun çözümüne bir nebze olsun katkı sunulması hedeflenmektedir. Buna mukabil, her ne kadar Mûsâ'nın temsil ettiği zâhir ilmi ile Hızır'ın muttali kılındığı bâtın ilmi arasındaki ikilem, kıssanın ihtiva ettiği önemli temalardan biri olsa da bunun bâtınî/işârî yorumlarla ilgili olduğunu söylemek pek mümkün gözükmemektedir. Zira olayın -ister görünen veçhesi, isterse perde arkasından söz edilsin- her ikisi de biri beşerî, diğeri ilahî olmak üzere hakikatin iki ayrı yüzünü temsil etmektedir. Bu itibarla sûfî gelenekte olduğu gibi Hızır'ın çocuğu öldürmesinin nefs-i emmâreyi öldürmesinin sembolü olduğu biçimindeki yorumlarla ilgilenilmeyecektir.

Günümüzde yapılan farklı akademik araştırmalarda Hızır-Mûsâ kıssası muhtelif yönleriyle ele alınmıştır. Bu çerçevede genel olarak, kıssanın tefsir hadis ve tasavvuf literatüründeki yerine, olayın aktörlerini olușturan Hızır, Yûşâ ve Mûsâ'nın kimliğine, Yahudi kültürü, Gılgamış ve İskender Destanıyla ilişkili olup olmadığı hususundaki tartışmalara, olayın kader perspektifinden okunmasına ve İsrâiliyyat'la ilişkisine değinilmiştir. ${ }^{4}$ Bu araștırmada ise Hızır-Mûsâ kıssasında anlatılan olaylar dizgesinde anlaşılması en zor gözüken, günümüzde farklı okumalara konu olan ve özellikle birtakım araştırmacılar tarafından adalet ve ahlak ilkesi ekseninde sorunlu addedilen çocuğun öldürülme meselesine odaklanılacaktır. Bu açıdan kıssada yer alan olay örgüsünün ve bu anlatıda kullanılan dilin sınırlarını aşmadan çocuğun öldürülme hadisesini, Kur'an bütünlüğünü dikkate alarak okumaya ve bu olayla ulaşılmak istenen hedefleri tespit etmeye çalışacağız. Buna göre çalışmada ilk olarak Kur'an'da Hızır-Mûsâ kıssasının genel hatlarıyla anlatımına yer verilecektir. Daha sonra düşünsel bir perspektif oluşturmak için tarihten günümüze tefsir literatüründe çocuğun öldürülme meselesinin genel olarak nasıl izah edildiği ortaya konulacaktır. Ardından bu hadisenin Kur'an'ın anlam ve değer dünyası açısından nasıl anlaşılması gerektiği üzerinde durulacaktır. Bu bağlamda çalışmamızda anlam ve değer tabirlerini felsefi bir düzlemde değil daha çok lugavî çerçevede kullandığımızı belirtmeliyiz. Bu bakımdan kıssadan çıkarılabilecek sonuç ve bu sonucun muhatap üzerindeki etkisi yönüyle konuya yaklaşılacaktır. Böylece çocuğun öldürülme hadisesine yönelik ortaya konulan anlama ve yorumlama çabalarına bir katkı sunulmaya çalışılacaktır.

\footnotetext{
${ }^{4} \mathrm{Bu}$ çerçevede yapılan bir kısım çalışmalar için bk. Mustafa Öztürk, "Bilge Kul-Musa Kıssası ve İslam Kültüründe Hızır Mitosu”, Ondokuz Mayıs Üniversitesi İlahiyat Fakültesi Dergisi 14/15 (2003), 245281; İman bint Abdurraḥmân Maḥmûd Mağribî, "Hz. Musa ve Hızır (as) Kıssası: İsrâîliyyât Rivâyetlerine Karşı Eleştirel Bir Yaklaşım”, çev. Mustafa Şentürk, Amasya Üniversitesi İlahiyat Fakültesi Dergisi 5 (2015), 173-208; Yasin Meral, "Mûsâ-Hızır Kıssası ve Kıssasının Yahudi Kökeniyle İlgili İddialarının Değerlendirilmesi”, Ankara Üniversitesi İlahiyat Fakültesi Dergisi 55/2 (2014), 129-150; Necmettin Çalıșkan, "Kehf Sûresi Bağlamında Hz. Mûsâ ve Sâlih Kul (Hızır) Kıssası ve Antakya'da Hızır İnancının Sosyo-Kültürel Etkileri”, Toplum Bilimleri Dergisi 9/18 (2015), 243-262; Kılıç Aslan Mavil, "Hızır-Mûsâ Kıssasında Kader - Çift Perspektifli Bir Bakıș -", Insan ve Toplum Bilimleri Araștırmaları Dergisi 5/8 (2016), 2496-2516. Makale düzeyindeki bu çalışmalara ek olarak bir kitap çalışması için bk. Necmeddin Bardakçı, Hakikatin Keşfi-Hz. Musa ve Hızır, 2. Basım (İstanbul: Rağbet Yayınları, 2019).
} 


\section{Ana Hatlarıyla Hızır-Mûsâ Kıssası}

Kur'an'da Kehf sûresinin 60-82. ayetlerinde İslam kültüründe Hızır-Mûsâ kıssası olarak bilinen olaya yer verilmiştir. Kıssayı şöyle özetleyebiliriz: Mûsâ, hizmetinde bulunan gençle birlikte Hızır'la buluşmak üzere iki denizin birleştiği yere gider ve burada Allah'ın kendi katından rahmetini lütfettiği ve özel bir ilim öğrettiği sâlih bir kulla karşılaşırlar. Bu kişinin adı Kur'an'da zikredilmese de hadislerde Hızır olarak ifade edilmiş, ${ }^{5}$ tefsir literatüründe de bu isimle meşhur olmuştur. ${ }^{6}$ Kendisine verilen özel ilimden öğretmesi talebine karşı Hızır Mûsâ'ya, beraberliklerine ve hakkında tecrübe sahibi olmadığı bir şeye katlanamayacağını söyleyerek bu konuda biraz çekimser kalır. Buna mukabil Mûsâ, beraber oldukları süre boyunca sabırlı davranacağına ve ona karşı gelmeyeceğine dair taahhütte bulunur. Bunun üzerine Hızır, kendisine tâbi olduğu takdirde anlatmadıkça hiçbir soru sormaması şartıyla Mûsâ'nın bu isteğini kabul eder ve birlikte yolculuklarına başlarlar.

Mûsâ ile Hızır ilk olarak bir gemiye binerler. Bir süre sonra Hızır gemiyi delince Mûsâ hemen "İçindekileri boğmak için mi gemiyi deldin! Gerçekten çok kötü bir iş yaptın!" şeklinde sert sözlerle bu duruma tepki gösterir. Hızır'ın ise, "Ben sana benimle beraber olmaya kesinlikle katlanamayacaksın demedim mi?" şeklinde karşılık vermesi üzerine Mûsâ, hemen geri adım atarak verdiği sözü unuttuğu için kendisini mazur görmesini ve daha fazla üzerine gelerek yolculuklarını çekilmez kılmamasını ondan rica eder. Derken yolda bir erkek çocukla karşılaşırlar ve Hızır hemen onu öldürür. Bunu gören Mûsâ yine kendini tutamaz ve "Bir cana karş̧llk olmaksızın suçsuz birini mi öldürdün! Gerçekten çok kötü bir iş yaptın." şeklindeki sözlerle rahatsızlığını bildirir. Bunun üzerine Hızır yine "Ben sana benimle beraber olmaya kesinlikle katlanamayacaksın demedim mi?" șeklinde karşıllk verir. Mûsâ da "Bundan sonra sana herhangi bir şey hakkında soru sorarsam benimle bir daha arkadaşlık etme. Zaten sen artık benden yana mazur sayılacak duruma gelmiş bulunuyorsun" diyerek Hızır'a hak verir. Tekrar birlikte yola koyulurlar ve bir yerleşim yerine uğrarlar. Belde sâkinlerinden, karınlarını doyurmak için kendilerine yiyecek vermelerini talep etmelerine karşın onlar bu isteğe olumlu karşllk vermez ve misafirperverlik göstermezler. Ardından aynı yerde yıkılmaya yüz tutmuş bir duvar görürler ve Hızır hemen o duvarı tamir eder. Bunun üzerine Mûsâ yine sabredemeyerek; "Dileseydin yaptığın bu iş için bir ücret alabilirdin." diyerek duruma itiraz eder. Mûsâ'nın bu son sözleri üzerine Hızır, artık yol ayrımına geldiklerini ve şimdiye kadar sabredemediği olayların iç yüzünü açıklayacağını ona bildirir.

Hızır gemiyi delmesinin gerekçesini; "O gemi denizde çalışan yoksul birtakım

${ }^{5}$ Anılan kıssada Hızır ismi yer almamakla beraber İslamî kaynaklarda bu şekilde meşhur olduğundan bu ismi kullanmayı tercih ettik. bk. Ebū Abdillāh Muhammed b. İsmāīl el-Buhāāī, el-Cāmi'u'ṣ-șahịḥ, nșr. Muhammed Züheyr b. Nașr, 9 Cilt (b.y.: Dāru Tavkị'n-Necāt, 1422/2001), “īlim”, 3 (No. 74); Ebü'lHüseyn Müslim b. el-Haccāc, el-Cāmi'u'ș-șahịhh, nşr. Muhammed Fuād Abdülbāḳī, 5 Cilt (Kahire: y.y., 1374-75/1955-56), "Fezāiil", 46 (No. 2380).

${ }^{6}$ bk. Ebü'l-Hasen Muḳātil b. Süleymān b. Beşīr el-Ezdī el-Belh̄ī, Tefsīru Mukātili, thk. Abdullāh Mahmūud Şehhhāte, 5 Cilt (Beyrut: Dāru İhyāi't-Türās, 1979), 2/594; Ebū İsḥāk İbrāhīm b. es-Serī b. Sehl ezZeccāc, Me'āni'l-Kur àn ve i'rābüh, 5 Cilt (Beyrut: Âlemü'l-Kütüb, 1408/1988), 3/299. 
kimselere aitti. Onların önlerinde her sağlam gemiyi zorla almak isteyen bir kral vardl. Bu yüzden o gemiyi kusurlu hâle getirmek istedim." şeklindeki sözlerle izah eder. Çocuğu öldürmesinin gerekçesini ise; "Anne babası mümin insanlardı, onları azgınlığa ve küfre sokmasından korktuk. (O çocuğu öldürmekle) Rablerinin onlara bu çocuğun yerine daha temiz, daha hayırlı ve daha merhametli olanını vermesini istedik." sözleriyle açıklar. Duvarı düzeltmesinin nedenini ise "Duvar, şehirdeki iki yetim çocuğa aitti. Altında onlara ait bir hazine vardı. Babaları da sâlih bir insandı. Rabbin onların olgunluk çağına erişmelerini ve Rabbinden bir rahmet olarak o hazineyi çıkarmalarını murat etti." sözleriyle anlatır. Ardından kıssa Hızır'ın, Mûsâ'ya bütün bunları kendiliğinden yapmadığını ve sabredemediği olayların hakikatlerinin bu șekilde olduğunu söylemesi üzerine sona erer.

\section{Tefsir Literatüründe Çocuğun Öldürülme Meselesi}

Bir önceki başlıkta kısaca arz ettiğimiz gibi kıssanın ayrıntılarında yer alan ve Mûsâ'nın tepki ve itirazlarına neden olan geminin delinmesi, çocuğun öldürülmesi ve duvarın düzeltilmesi gibi eylemlerin başlangıçta normal karşılanmaması doğaldır. Telafisi nispeten imkân dâhilinde olan diğer iki olaya göre arka planı bilinmeksizin çocuğun birdenbire öldürülmesine tanık olunmasının insan vicdanında büyük bir rahatsızlığa yol açması elbette beklenen bir durumdur. Çünkü zâhiren haklı bir nedene dayanmayan bu tür olaylar hayatın olağan akışına aykırıdır. Nitekim Kur'an'da, bir cana ya da yeryüzünde bir fesada karșlık olmaksızın herhangi birisinin öldürülmesinin bütün insanlığı öldürmek anlamına geldiğinin vurgulanmasında da bu ahlâkî ve vicdânî boyutun göz ardı edilmediği anlaşılır.7

$\mathrm{Bu}$ durum göz önünde bulundurulmak üzere, müfessirlerin erken dönemden itibaren kıssadaki çocuğun öldürülme meselesinde Allah'ın hikmetini anlama ve açıklama çabasına girdikleri görülür. Ne var ki müfessirler genellikle, çocuğun öldürülmesini hukûkî zeminde izah etmeye ve konuya hukûkî bir meşruiyet bulmaya çalışmışlardır. Bu sebeple onlar, genel olarak çocuğun yaşı ve öldürülme nedeni üzerinde yoğunlaşmışlar ve bu bağlamda farklı görüşler ortaya koymuşlardır. Buna göre onların bir kısmı çocuğun büluğ çağına eriştiğini söylerken diğer bir kısmı henüz büluğ çağına gelmediğini iddia etmişlerdir. ${ }^{8}$ Buna ek olarak bazı mü-

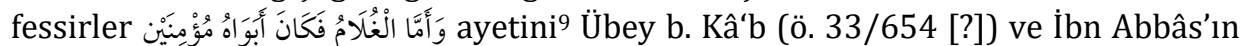

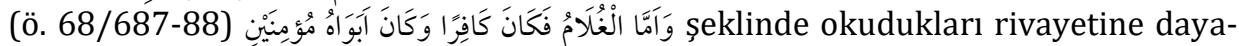
narak çocuğun kâfir olduğunu ileri sürmüşlerdir. ${ }^{10} \mathrm{Bu}$ iki yaklaşıma göre çocuğun

\footnotetext{
${ }^{7}$ el-Mâide $5 / 32$.

8 bk. Ebü'l-Leyś es-Semerḳandī, Bahru'l-'ulūm, 3 Cilt (b.y.: y.y., ts.), 2/356; Ebū Abdullāh Muhammed b. Ömer Fahruddīn er-Rāzī, Mefātịhu'l-ġayb, 32 Cilt (Beyrut: Dāru İhyaāi't-Türās̄i'l-'Arabī, 1999), 21/391; Ebū Abdullāh Muhammed b. Aḥmed el-Kurtubī, el-Cāmi' li ahkāmi'l-Kurūān, thk. Aḥmed Berdūnī, 20 Cilt (Kahire: Dāru'l-Kutubi'l-Mıșriyye, 1964), 11/22; Muhammed b. Ali b. Muhamammed eş-Șevkānī, Fethu'l-kadìr, 6 Cilt (Beyrut: Dāru İbn Kesīr, 1993), 3/359.

${ }^{9}$ el-Kehf $18 / 80$.

${ }^{10}$ Muhammed b. Cerīr Ebū Ca'fer et-Ṭaberī, Cãmi'u'l-beyān fì te'vili'l'l'-Kurrānn, thk. Aḥmed Muhammed Şākir, 24 Cilt (Beyrut: Müessesetü'r-Risāle, 2000), 18/85; Ebū Muhammed Abdurrahmān b. Ahmed b. Ebī Hâtim er-Rāzī, Tefsìru İbn Ebì Hātim, thk. Esad Muhammed et-Ṭayyib, 10 Cilt (Suūd: Mektebetü Nizār Muștafā el-Bāz, 1419/1998), 7/2380.
} 
öldürülme gerekçesi farklılık göstermektedir. Çocuğun büluğ çağına eriștiği görüşünü benimseyen âlimlere göre, büluğ çağına erişmeyen çocuklar mükellef/sorumlu tutulamayacağından, günah işlemeleri onların öldürülmesi için haklı bir gerekçe oluşturmaz. ${ }^{11} \mathrm{Bu}$ açıdan ayette geçen غلام (gulām) kelimesinin Arapların kullanımına işaret edilerek, "büluğ çağına henüz yeni ermiş ve sakalları gürleşmemiş delikanlı" anlamına geldiğini ifade etmişlerdir. ${ }^{12}$ Ayrıca غلام kelimesinin karşı cinse aşırı şehvet ve düşkünlük duymak manasına gelen غاغِتلام (iǵtilām) kelimesiyle aynı kökten türediğine dikkat çekilerek bu görüş pekiştirilmiştir. ${ }^{13}$ Buna göre ayette bahsedilen çocuğun, hem mükellef hem de kâfir olmasına binaen öldürülmeyi hak ettiği düşünülmektedir.

Muḥammed b. Sâib Kelbî̀ye (ö. 146/763) göre kâfir olan bu çocuk eşkiyalık yapan, yol kesen, halkın mallarını gasp edip anne babasına getiren birisiydi. Bir diğer açıllamaya göre o, insanlara zulmeder ve anne-babasını çok üzerdi. Annebabası, çocuklarının zulmünden ve halkın şikâyetinden bıkarak onu azarlarlardı. ${ }^{14}$ Buna karşılık o, Allah’a yemin ederek suçlamaları reddederdi. Ettiği bu yeminlere inanan anne-babası çocuklarının bu tür kötülüklerle ilgisi bulunmadığına ikna olurlardı. Hızır'a gelince o, Allah'ın kendi katından verdiği ilimle bu çocuğun fesat çlkaran birisi olduğunu bildiğinden onu öldürmüştür. ${ }^{15} \mathrm{Bu}$ itibarla, "Biz o çocuğun, anne-babasını küfre ve tuğyana sevk etmesinden korktuk." ayetindeki فخشينا "korktuk" ifadesinin فعنمن "bildik" anlamında kullanıldığı ifade edilmiştir. ${ }^{16}$ Dolayısıyla bu yaklaşıma göre ergenlik çağında olan bu çocuk fesat çıkarması ve insanlara zulmetmesi sebebiyle öldürülmeyi hak etmiştir. Ancak bu bilgi Mûsâ'ya gizli olduğu için o, bu duruma itiraz etmiştir.

Bu bağlamda Hz. Peygamber'den şöyle bir rivayet nakledilmiştir: "Hızır'ın öldürdüğü çocuk, her şeyin mühürlendiği gün kâfir olarak mühürlenmiştir."17 Taberî (ö. 310/923) bu rivayetle ilişkili olarak Katâde'den (ö. 117/735) "Şayet çocuk yaşamış olsaydı anne babasını helak edecekti." şeklinde bir görüş rivayet etmiştir. Bu açıdan Țaberî̀ye göre her müminin Allah'ın kazasına rıza göstermesi gerekir. Öyle ki bazen Allah'ın, insanların hoşuna gitmeyen bir kazası, olmasını arzu ettikleri bir durumdan daha hayırlı olabilir. ${ }^{18}$ Dolayısıyla bu görüșe göre Allah'ın ezelî ilminde çocuğun kâfir olduğuna ve ileride anne-babasını helak edeceğine dair bilginin $\mathrm{H}_{1}-$ zır’a verilmesi, çocuğun öldürülme gerekçesini oluşturmuştur. Taberî, çocuğun öldürülme sebebi üzerinde durduktan sonra bir bütün olarak Hızır-Mûsâ kıssasının Kur'an'da anlatılmasının nüzul dönemi açısından temel maksatlarına da de-

\footnotetext{
${ }^{11}$ Muḳātil, Tefsîru Mukātil, 2/598; Ebū Manșūr el-Mātürīdī, Tévīlātü'l-Kur'ān, thk. Murat Sülün, 17 Cilt (İstanbul: Dāru'l-Mīzān, 2018), 9/94; Kurțubī, el-Câmi' li ahkāmi'l-Kurr'ān, 11/22.

12 Muḳātil, Tefsîru Mukātil, 2/598; Ebû Muḥammed Abdülḥaḳ b. Ġâlib İbn Aṭiyye, el-Muharrerü'l-vecīz, thk. Abdüsselām Abduşşāfi' Muḥammed, 6 Cilt (Beyrut: Dāru'l-Kutubi'l-İlmiyye, 1422/2001), 3/536.

13 Semerkandī, Bahru'l-'ulūm, 2/356; Rāzī, Mefātīḥu'l-ġayb, 21/391.

14 Semerḳandī, Baḥru'l-‘ulūm, 2/357; Muḳātil, Tefsīru Mukātil, 2/598.

${ }^{15}$ Muḳātil, Tefsīru Mukātil, 2/598.

${ }^{16}$ Mukātil, Tefsīru Muḳātil, 2/598; Rāzī, Mefātīhu'l-ġayb, 21/39; İbn Aṭiyye, el-Muharrerü'l-vecīz, 3/536.

17 Taberī, Cāmi'u'l-beyān, 18/85; Müslim, "Feẓāil", 43 (No. 2661).

18 Ṭaberī, Cāmi'u'l-beyān, 18/87.
} 
ğinmiştir. Ona göre bu olayın Kur'an'da yer almasının amacı, Hz. Peygamber'i bu kıssa üzerinden eğitmektir. Bu kıssadaki anlatıma göre, hâlihazırda belli bir güç ve otoriteye sahip olsalar da Müşriklerin sonlarının geleceği vurgulanmış olmaktadır. Bu sayede Hızır-Mûsâ kıssası üzerinden Hz. Peygamber'e, hiçbir şeyin görüldüğü gibi olmadığı, varlığın görünen yüzünün ardındaki hakikatlerin tam anlamılla kuşatılamayacağı ve hakikat ortaya çıkıncaya dek Müşriklerin cezalandırılmasında acele edilmemesi ve onların inkârına sabredilmesi mesajı verilmiştir. ${ }^{19}$

Mâtürîdî ise öncelikle işin hakikatini en iyi bilenin Allah olduğunu vurgulamıştır. Ona göre Hızır'ın çocuğu niçin öldürdüğünü, yaşının kaç olduğunu bilmeye ihtiyacımız yoktur. Zira son tahlilde Hızır çocuğu kendiliğinden değil, Allah'ın emri üzerine öldürmüştür. ${ }^{20}$ Hüküm ve yetki Allah'ın elindedir. ${ }^{21}$ Öyle olunca Allah ölüm meleğini göndererek dilediği insanın canını, dilediği yaşta alabilir. ${ }^{22} \mathrm{Bu}$ kısa, öz ve ikna edici gibi görünen izaha ek olarak Mâtürîdî, konuyla ilgili hâsıl olan bazı müşkilleri çözmeye, muhtemel soruları yanıtlamaya çalışmış ve bu çerçevede şöyle bir itiraza yer vermiştir:

"Allah, çocuğun anne-babasını küfre ve tuğyana düşüreceğini bilmesini, nasıl olur da onun öldürülmesine delil olarak gösterir? Zira Allah, İblis ve askerlerinin, dünyanın sonu gelene kadar yaşamalarına izin vermiștir. Allah, bu varlıkların insanları azgınlık ve nankörlüğe sevk edeceklerini, çeşitli günahlara ve kötü fiillere yönelteceklerini biliyordu. İnsanlara kötülük ve zulümden başka bir şeyi reva görmeyen zalimler hakkında da aynı durum söz konusudur. Allah bu kimseleri, zülüm yapacaklarını bildiği halde yaşatır. 0 halde Allah, çocuğun öldürülmesini nasıl olur da ileride anne-babasını azgınlık ve nankörlüğe sevk edecek olmasıyla gerekçelendirir?"23

Mâtürîdî bu itirazı, çocuğun öldürülmesinin bir imtihan vesilesi olması ve Allah'ın lütuf ve ihsanının farkı tezahürlerini onlara gösterme amacı bulunması yönünden cevaplamaya çalışır. Bu minvalde Allah'ın, insanları imtihana tâbi tuttuğu olaylara ve sebeplere teşvik ettiğinden ve içlerinde bu yönde bir arzu uyandırdığından söz eder. Ayrıca insanları sevap ve mükâfatın aracı olan birtakım ibadet ve tâatle imtihan ettiği ve bu görevleri yaptıkları takdirde kendilerine sevap verileceğini bildirdiği, insanın karşılaştığı cezalar ve sıkıntıların da böyle olduğuna dair açılklamalara yer vermiştir. ${ }^{24}$ Buna göre Allah bazen zalimlere mühlet vererek, bazen de canlarını alarak onları sınar. Diğer taraftan her şeye kâdir olan Allah lütuf ve ihsanda bulunurken de her şeyde bir denge gözetir. ${ }^{25}$ Dolayısıyla Allah, lütfu ve ihsanı gereği dengeleri sağlamak için küfür ve azgınlık içinde olan birtakım kimselerin ölmesini dilerken, diğer birtakım kimselerin yaşamalarına müsaade eder. Kısaca söylenecek olursa, Mâtürîdî ayette çocuğun öldürülme meselesini Allah'ın

\footnotetext{
19 Taberī, Cāmi'u'l-beyān, 18/91.

20 el-Kehf $18 / 82$.

21 el-A'râf 7/54.

${ }^{22}$ Mātürīdī, Tévīlātü'l-Kur'ān, 9/93.

${ }^{23}$ Mātürīdī, Te'vīlātü'l-Kur'ān, 9/94.

${ }^{24}$ Mātürīdī, Te'vīlātü'l-Kur'ān, 9/94.

${ }^{25}$ Mātürīdī, Te'vīlātü'l-Kur'ān, 9/94.
} 
hikmeti, ilmiyle her şeyi kuşatması, ihsanı, lütfu ve kullarını farklı şekillerde imtihan etmesi açısından izah etmiştir.

Mu'tezilî âlimlerden Hâkim el-Cüșemî (ö. 494/1101), çocuğun öldürülme gerekçesini müteşabihin beyanı, yani insanın bilgi düzeyini ve idrak sınırını aşan hakikatlerin insana açıklanması olarak tarif etmiştir. ${ }^{26}$ Diğer bir Mu'tezilî âlim olan Zemahşerî (ö. 538/1144) çocuğun öldürülmesine dair Hâricilerin Necedât kolu lideri olan Necdet b. Âmir el-Harûrî̀nin (ö. 72/691) İbn Abbâs'a "Hz. Peygamber çocukların öldürülmesini yasaklamasına rağmen nasıl olur da bir çocuğun öldürülmesi caiz olur?" şeklinde bir soru sorduğunu, İbn Abbâs'ın buna "Şayet o çocuk hakkında Mûsâ'nın beraberindeki o âlimin bildiklerini bilmiş olsaydın, senin de o çocuğu öldürme hakkın olurdu." diye cevap verdiğini anlatır. ${ }^{27} \mathrm{Bu}$ rivayeti esas alan Zemahşerî̀ye göre Allah, Hızır'a çocuğun hâlini bildirmiş ve onu öldürmesini emretmiştir. 0 bu durumu, bir başkasını fesada sevk edeceği bilinen bir kişinin kökünün kazınmasına (öldürülmesine) benzetmiştir. ${ }^{28}$ Zemahşerî̀nin bu son ifadeleri, böyle bir bilgiye başkalarının da vâkıf olması durumunda bir çocuğun öldürülmesinin câiz olup olmadığı sorusunu akla getirir. Nitekim bu soruya bu tür bilgilerin vahiy kaynaklı olup ancak peygamberlerden sâdır olabileceği şeklinde cevap verilmiştir. ${ }^{29} \mathrm{Bu}$ çerçevede Râzî̀nin (ö. 606/1210); “Çocuğun anne-babasını küfür ve azgınlığa sürükleyecek olması zannından dolayı öldürülmesi caiz midir?" yönündeki bir soruya; "Eğer bu zan vahiyle kesinleșirse caiz olur." şeklinde cevap vermesine ${ }^{30}$ bakılırsa onun da Zemahşerî ile temelde aynı görüşte olduğu sonucu çıkarılabilir.

Kurțubî (ö. 671/1273), Hızır'ın öldürdüğü çocuğun Allah'ın ezeli ilminde kâfir olarak mühürlendiğini bildiren hadisin zâhirinin çocuğun bâliğ olmadığı görüşünü desteklediğini belirtmiştir. ${ }^{31}$ Buna mukabil o, konuya șerî̀ açıdan yaklaşmış, bu husustaki kıraat vecihlerini ve diğer rivayetleri delil olarak kullanmıştır. Böylece çocuk hakkında kâfir sıfatının kullanılmasının ancak bâliğ olması hâlinde söz konusu olacağını vurgulamıştır. ${ }^{32}$

Modern dönemde yazılan tefsirlerde de konu, çeşitli biçimlerde açıklanmaya çalışılmıştır. Bu tefsirlerin bir kısmında, Hızır’ın başkalarına ait gemiyi delmesi ve suçsuz bir çocuğu öldürmesini hukûkî ilkelerle açıklamanın imkânsızlığından hareket edilmiştir. Mevdûdî (1903-1979) Hızır'ın gemiyi delmesi ve çocuğu öldürmesinin insanın yaratılışından beri var olan kanunlarla açıkça çeliştiğini ifade etmiştir. Zira hiçbir kanun başkasına ait geminin delinmesine ve suçsuz bir insanın öldü-

${ }^{26}$ Ebū Sa'd Müḥsin b. Muhammed Ḥākim el-Cüșemī, et-Tehżīb fi't-Tefsīr, thk. Abdurraḥmān b. Süleymān es-Sālimī, 10 Cilt (Kahire: Dāru'l-Kutubi'l-Mıșrī, ts.), 6/4476.

27 Ebü'l-Ḳāsım Maḥmūd b. 'Amr Cārullah ez-Zemahş̧erî, el-Keşșāf 'an hạakāiḳı ġavāmızi't-tenzīl, 4 Cilt (Beyrut: Dāru'l-Kutubi'l-Arabiyye, 1988), 2/736. Ayrıca bu rivayet için bk. Müslim, "Cihād”, 32 (No. 1445); Semerkāndî, Bahru'l-'ulūm, 2/356.

${ }^{28}$ Zemahșerī, el-Keșşāf, 2/741.

${ }^{29}$ Cüșemī, et-Tehzīb fi't-Tefsīr, Rāzî, Mefātīhu'l-ġayb, 21/40.

${ }^{30}$ Rāzī, Mefātīhu'l-ġayb, 21/491.

31 Ṭaberī, Cāmi'u'l-beyān, 18/85; Müslim, "Feẓāil”, 43 (No. 2661).

32 Kurțubī, el-Cāmi' li ahkāmi'l-Kur'ān, 11/22. 
rülmesine yetki vermez. Öyle ki herhangi bir insan ileride bir çocuğun isyankâr ve kâfir olacağını ilham yoluyla bilse dahi böyle bir hakka sahip olamaz. Bu noktada, Mevdûdî emrin niteliği ve özelliği üzerinde yoğunlaşılması gerektiğini belirtmiştir. Buna göre Hızır'a verilen emir şer'î ve hukûkî bir nitelikte değildir. Mevdûdî, şer'î değer taşıyan hükümlerin insanlar için konulduğuna işaret ederek, Hızır'ın melek olduğu ve meleklerin Allah'ın emriyle bu tür eylemlerde bulunabileceği iddiasında bulunmuştur. Ona göre insanlara bildirilen ilahî emirlerle meleklere bildirilen emirler arasında fark vardır. Bu ikinciler, Allah'ın kimini fakir ve hasta, kimini de zengin ve sağlıklı kılmasıyla aynı kategoride yer alırlar. ${ }^{33}$ İbn Âşûr (1879-1973) da ayette çocuğun öldürülmesinin teşri' makamında değil, Allah'ın ilmi ve lütfunun sınırsız oluşu bağlamında ele alındığını söyleyerek meseleye Mevdûdî ile aynı doğrultuda yaklaşmıştır. ${ }^{34}$

Klasik dönem müfessirlerinin konuya dair açıklamalarında, olayın hukûkî veçhesiyle kader planına göre gerçekleşeceği belirtilen ilahî boyutunun iç içe geçtiği, hatta birbirine karıştırıldığı söylenebilir. Öldürülen çocuk, hukûkî sorumluluğa sahip olsa da bu bağlamda ona nispet edilen çirkin fiillerin onun öldürülmesini mucip gerekçeler olabileceğinin söylenmesi pek makul gözükmemektedir. Bu durumda müfessirlerin çocuğun bâliğ olduğunu dile getirmelerinin ve açılamalarını buna göre temellendirmeye çalışmalarının meseleyi çözüme kavuşturmada yetersiz kaldığı müşahede edilmektedir. Müfessirlerin, bu açıklamalarına destek olmak üzere Übey b. Kâ'b ile İbn Abbâs'tan nakledilen ve çocuğun kâfir olduğu anlamına gelen kıraat rivayetiyle Hızır'ın öldürdüğü çocuğun kâfir olduğunu bildiren hadisini delil olarak kullanmalarıyla ilgili şunları söyleyebiliriz: Anılan kıraat vechi delil olarak kullanıldığında çocuğun kâfir olduğu anlaşılsa bile bunun, șerî̂ anlamda çocuğun öldürülmesine tek başına sebep sayılabileceğini söylemek zordur. Öte yandan çocuğun kalbinin küfürle mühürlendiği şeklinde ilahî takdire bağlı bir tasarrufun söz konusu olduğunu bildiren hadis rivayetinin hukûkî bir içeriğe sahip olduğu söylenemez. İbn Ațyye (ö. 541/1147) ve Kurțubî̀nin -bu yönde aksi görüşü benimsemiş olsalar da- hadisin zâhirinin çocuğun küçük olma ihtimalini desteklediğinden bahsetmelerij ${ }^{35}$ konunun hukûkî bir zeminde ele alınmasının isabetsizliğini teyit eder. Böylece anılan durumun farkında gözüken kimi müfessirlerin meseleyi Allah'ın takdirine havale etmelerinden bu anlaşılmaktadır. Konuyla ilgili yukarıda arz ettiğimiz farklı görüşleri zikreden Mâtürîdî”nin "Bizim çocuğun öldürülme nedenini bilmeye ihtiyacımız yoktur. Çünkü Hızır, bu işi Allah'ın emriyle yaptığını bildirmiş̧ir. Allah'ın bir kuluna, küçük bir çocuğu öldürme emri vermesi ve bu fiili ister doğrudan, isterse ölüm meleğine emrederek yerine getirmesi mümkündür. Zira hüküm O'na aittir." şeklindeki ifadelerle meselenin nasıl bir boyutta düşünülmesi gerektiğine dair son derece isabetli bir değerlendirmede bulunduğu görül-

${ }^{33}$ Mevdūdī, Tefhīmu'l-Kur'ān, çev. Muhammed Han Kayani vd., 7 Cilt (İstanbul: İnsan Yayınları, 2005), 3/190.

34 Muhammed et-Ṭāhir b. Muhammed İbn Āșūr, et-Taḥrīr ve't-tenvīr, 30 Cilt (Tunus: Dāru'l-Tūnisiyye, 1984), 16/13.

35 İbn Ațyye, el-Muharraru'l-vecīz, 3/536; Kurțubī, el-Cāmi' li aḥkāmi'l-Kur'ān, 11/36. 
mektedir. ${ }^{36}$

Buraya kadar söylenenleri özetleyecek olursak bir kısım âlimler, Hızır-Mûsâ kıssasında çocuğun ergenlik çağında olduğu, fesat çıkardığı ve zulmeden bir kâfir olduğu gerekçesiyle öldürülmeyi hak ettiğini belirterek meseleyi çözmeye çalışmışlardır. Diğer bir kısım âlimler ise meseleye Allah'ın ilmi, lütfu ve her şeyi kuşatması açısından bakmışlar ve bu yönüyle öldürülen çocuğun küçük yaşta olmasinda bir beis görmemişlerdir. Zira bu âlimlere göre burada anlatılmak istenen, haksız yere bir çocuğun öldürülüp-öldürülemeyeceği değil, insanın idrak alanının ve bilgi edinme imkânlarının sınırlılığı ile Allah'ın ilminin her şeyi kuşattığı, dolayısıyla O'nun kaza ve takdirine boyun eğilmesi gerektiğidir. Böylece klasik tefsirlerde yapılan açıklamaların genellikle hukûkî çerçeveye bağlı kaldığı, modern yorumlarda ise olayın ilahî ve ontolojik boyutuna dikkat çekildiği görülmektedir.

\section{3. Çocuğun Öldürülme Meselesinin Anlam ve Değer Açısından İnce- lenmesi}

Bilindiği üzere Mu'tezile kelamında Allah mutlak adil olduğundan O'nun çirkin ve kötü bir fiili emretmesi mümkün değildir. Çünkü onlara göre bir eylemin adil olup olmadığının tespiti hususunda ölçü insan aklıdır. Bu yüzden Allah'ın insan aklı tarafından maruf ve hikmetli görüneni yaratması vaciptir. ${ }^{37}$ Eşarilik'te benimsenen düşünceye göre bu hususta insan aklı yetersizdir. Çünkü maruf ve hikmetli olanı gerçek anlamda sadece Allah bilir. ${ }^{38}$ Bunun için adaletin tesisi insan aklıyla değil Allah'ın emirlerine uymakla mümkündür. Mâtürîdîlik'te ise konunun izah edilmesinde Allah'ın adil oluşu ile bunun insan aklıyla kavranabilirliği arasında bir denge kurulmaya çalışılmıştır. Bu itibarla, Allah'ın yarattı̆̆ı ve emrettiği her şey maruf ve güzel, yasakladığı her şey de çirkin ve değersizdir. Ancak bunun kavranmasında insan aklına bahședilen yetenek sınırlı düzeydedir. ${ }^{39}$ Böylece Mâtürîdî’nin konuyu hikmet kavramıyla izah etmeye çalıştığı görülmektedir. Ona göre Allah'ın varlık ve eşya üzerindeki tasarruflarına ilişkin maruf ve güzel olanı insanın her zaman kavraması mümkün olmayabilir. Bu durumda insan aklının çirkin addettiği bir durum Allah'ın hikmeti açısından maruf olabilir. Söz gelimi Allah, kulunu kimi zaman fakirlik, hastalık, ölüm gibi çeşitli musibetlerle imtihan ettiğinde o, bunun kendisi için hayırlı bir durum olduğunu anlamayabilir. ${ }^{40}$

Böylece ilahî adalet noktasından hareket eden Mu'tezile'ye göre Allah'ın dünyevî hukuk normlarına göre görünür bir sebep olmaksızın masum bir çocuğun öldürülmesini emretmesi mümkün değildir. Mâtürîdî ise Allah'ın lütfu, ihsanı ve hikmeti noktasından meseleye bakmış ve bir imtihan aracı olarak çocuğun öldü-

\footnotetext{
${ }^{36}$ Mātürīdī, Te'vīlātül-Kur'ān, 7/200.

${ }^{37}$ Kaaḍi Abdülcebbār, Şerḥu Ușūli'l-Hamse, çev. İlyas Çelebi, 2 Cilt (İstanbul: Türkiye Yazma Eserler Kurulu Bașkanlı̆̆ 2013$), 2 / 354$.

${ }^{38}$ Murteza Muțahhari, Adl-i İlāhî, çev. Hüseyin Hatemî (İstanbul: Kevser Yayınları, 2. Basım, 2014 ), 22.

${ }^{39}$ Nūruddîn es-Ṣābūnî, el-Bidāye fî ușūli'd-Dîn, thk. Bekir Topaloğlu (İstanbul: İfav Yayınları, 11. Basım, 2013), 130.

40 bk. Osman Oral, "Kelam İlminde İlahi Adalet", Kelam Araştırmaları Dergisi [Kader] 11/1 (2013), 452455 .
} 
rülmesinin emredilmesini caiz görmüștür. Buna karşın Eş’arîler bu hususta herhangi bir gerekçe göstermeye ihtiyaç duymaksızın bunun mutlak manada mümkün olduğunu ileri sürmüşlerdir. ${ }^{41}$ Biz meseleye, daha dengeli bir bakışı yansıtması itibariyle Mâtüridî'nin yaklaşımını esas alarak bakacak olursak, Allah'ın adil oluşunun hiçbir varlığın hakkını ihlal etmemesi ve herkese hak ettiği karşılığı vermesi, hikmetli oluşunun ise en güzel ve en uygun olanı yaratması anlamına geldiğini söyleyebiliriz. ${ }^{42}$ Çünkü insan mutlak surette Allah'ın hikmetini ve adaletini kavramaktan acizdir. Bu nedenle Allah'ın adaletli ve hikmetli olması adaletin ve hikmetin kaynağının yine bizzat 0 olması demektir. ${ }^{43}$ Bundan dolayı gerçeği bütün yönleriyle kuşatamadığı için insanın iyi, kötü, güzel ve çirkin gibi değer yarglları itibari olmak durumundadır.

Diğer taraftan şer'î/hukûkî nitelikli naslarda Allah'ın kullarından olayların görünen veçhesine ve sebep sonuç ilişkisine göre hareket etmelerini istediği açıktır. Hz. Peygamber'in "Ben sadece bir beșerim. Bana hasımlar geldiğinde içlerinden birisi haklılığını daha etkili biçimde dile getirmiş olabilir. Böylece ben de onun doğru söylediğini zannederek lehine hüküm verebilirim..." ${ }^{44}$ meâlindeki hadisinin bu durumu yansıttığı görülür. Bu husus bir başka rivayette "Ben zâhire göre hükmetmekle emrolundum, iç dünyalara ise Allah hükmeder." şeklinde formüle edilmiştir. ${ }^{45}$ Hukuk normları da bu doğrultuda şekillenmiștir. Buna göre Allah'ın dokunulmaz kıldığı cana haksız yere kıymak meșru addedilmemiștir. İnsan tabiatı ve fitratı da buna uygun olarak teșekkül etmiștir. Bu nedenle Hz. Mûsâ'nın olayların zâhirinden hareketle kıssada anlatılan Hızır'ın gemiyi delmesi, çocuğu öldürmesi ve duvarı düzeltmesi karşslığında ücret almamasını önce kabul edilemez bulması sahip olduğu tabiattan kaynaklanır. Onun bu olaylara tepkisi, Hızır'ın eylemlerinin hiçbir haklı gerekçeye dayanmadığını zannetmesinden ileri gelmektedir. Diğer taraftan beşerin iradî davranışlarına taalluk eden hukûkî hükümler, aslı itibariyle ilahî kaynaktan beslense de son tahlilde her bir tekil olayla ilgili karar verme ve değer yargısı ortaya koyma yetkisi insana bırakıldığı için nesnel bir gerçeklik ifade etmeyebilir. Çünkü bu, olayların zâhirinden hareketle ortaya konan hükümlerden ibaret olması yönüyle bir sınırlılık ifade etmektedir. Dolayısıyla isabet etme ihtimali kadar hata etme ihtimalini de barındırır. Durum böyle olsa da insan hemcinsleriyle bir arada yaşarken bu normlara ve kararlara ihtiyaç duyar ve bu kurallar insan için bağlayıcılık arz eder.

Buna karşın, Allah'ın kulları ve evrenle ilişkili tasarruflarında beşerî anlamda bir hukûkî nitelikten söz edilemez. Çünkü varlığın mutlak bilgisi ve hâkimiyetini elinde tutan Allah'ın fiilleri hakikatin tam ifadesi olmak durumundadır. Bunun aksi, Allah'a eksiklik isnat etmek demektir. Mutlak kemal sahibi Allah'tan sudur eden bu

\footnotetext{
41 Mâtürîdî, Te'vîlâtü'l-Kur'ân, 9/94.

42 Muțahhari, Adl-i İlāhî, 71.

${ }^{43}$ Muțahhari, Adl-i İlāhî, 20.

44 Müslim, "Aḳzıye", 30 (No. 1713).

45 Muhammed b. İdrīs eş-Şāfīi, Müsned, nșr. Yûsuf Ali ez-Zevāvī - İzzet el-Atțār, 2 Cilt (Beyrut: Dāru'lKutubi'l-İlmiyye, 1370/1951), 1/13.
} 
fiillerdeki hikmetin ne kadarının ne zaman anlaşılabileceği sorusu konuyu kavramak açısından önemlidir. Kur'an'da Allah'ın fiillerinin, kulları tarafından anlaşılmasının her zaman mümkün olmadığı müteaddit defalar vurgulanmıştır. Bu konuda Allah, insanı varlık sahnesine çıkarmadan önce meleklerin kendisine bu husustaki kaygılarını bildirmesi üzerine "Ben sizin bilmediklerinizi bilirim" 46 buyurarak her türlü olumsuzluğa rağmen insanın var oluşundaki mana ve hikmetin meleklerce bilinemeyeceğini, oysa Allah'ın her yönüyle kuşatıcı bilgiye sahip olduğunu ifade etmektedir. "Hoşunuza gitmese de savaş size farz kılındı. Bir şeyden hoşlanmadığınız halde o sizin için hayırlı olabilir. Yine bir şey de hoşunuza gider, ancak bu sizin için kötü olabilir. Allah bilir, siz bilemezsiniz" 47 ayetinde de bir şeyin dış görünüşüne bakılarak her zaman iyi ya da doğru olduğunun söylenemeyeceği ve her şeyin içyüzünü Allah'ın bildiği dile getirilmektedir. Nûh Peygamber de Allah'ın mesajlarını kavmine aktarırken bildiklerini Allah'tan gelen vahiyle öğrendiğini anlatır. ${ }^{48} \mathrm{Bu}$ ve benzeri ayetlerde varlık ve olayların içyüzünün insan tarafından değil, Allah tarafından bilindiği dile getirilir.49 Benzer açıklama, Mûsâ'nın Hızır'dan kendisine verilen özel bilgiden öğretmesini talep etmesi üzerine "Íç yüzünü bilmediğin işlere nasıl sabredebilirsin ki?!"50 şeklinde verdiği karşılıkta da görülür.

Hz. Mûsâ'nın misyonu ve tabiatı gereği üst üste gösterdiği tepkiler üzerine Hızır, bu eylemleri kendiliğinden yapmadığını bildirmiştir. Zira Mûsâ, Hızır’ın bu eylemlerini beşeri perspektiften ve peygamberlik görevinin gereği olan bakış açısından hareketle adalet ve hikmete uygun bulmamış ve durumdan rahatsızlığını dile getirmiștir. Çünkü peygamberlerin ve diğer insanların sorumluluğu zâhire göre hüküm vermekle sinırlıdır. ${ }^{51}$ Onun bu tutumunun son derece doğal olduğunu kabul etmek gerekir. Çünkü o, peygamber de olsa aldığı vahiy dışında varlık ve hakikat hakkında sınırlı bir bilgiye sahiptir. 0 , diğer insanlar ve varlıklarla ilişkilerini de bu sınırlı bilgiyle sürdürmek durumundaydı. Şu halde kıssadaki eylemler, dünyevî boyutların ötesinde, insan bilgi ve gücünü aşan bir değer ve anlam taşır. $\mathrm{Bu}$

\footnotetext{
46 el-Bakara 2/30.

47 el-Bakara 2/216. İlhami Güler, insan tabiatının yanlış değerlendirmeler yapabileceğini kabul etmekle beraber bu ayette olayın insanlar tarafından doğru-yanlıș, iyi-kötü olarak nitelenmediğini, hoșlanılmayan şeylerin psikolojik ve içgüdüsel olduğunu ve buradan hareketle insanın ahlaki muhtevalı her tekil olayda doğru-yanlış, iyi-kötüyü çıkaramayacağını ileri sürmenin isabetsiz olduğunu dile getirir. bk. Güler, Allah'ın Ahlakiliği Sorunu, 38. Bu yaklaşım kısmen doğru olsa da Allah'ın fiilleri söz konusu olduğunda bazen zâhirde ahlâkî gibi görünmeyen olayların, özünde ahlâkî olduğu anlaşılır. Aynı şekilde ayette söz edilen konunun hiçbir ahlâkî içeriğe sahip olmadığı söylenemez. Zira ayetin içerdiği mesaj yeniden gözden geçirildiğinde günümüzde sözgelimi savaş karşıtı (pasifist) birisine, gerektiğinde hoşuna gitmese de düşmanla mücadelenin hayırlı, doğru ve ahlâkî olduğu şeklinde bir ögüt içerdiğini söylemekte bir sakınca olmasa gerektir. Diğer taraftan bu durum Güler'in Kur'an ahlakını temellendirdiği niteliklerden "faydalı olması" vasfına da uygundur. bk. Güler, Allah'ın Ahlakiliği Soru$n u, 35$. Zira düşmanla mücadele, toplumsal bir menfaatin sağlanması, mefsedetin def edilmesi amaclna matuftur. Dolayısıyla, düşman saldırılarına karşı hâlâ savaş karşıtlığı yapılmasının ahlâkî bir boyutu olduğu unutulmamalıdır.

48 el-A'râf 7/62.

${ }^{49}$ Diğer ayetler için bk. el-Enfâl 8/61; en-Nahl 16/8, 74; en-Nûr 24/19; er-Rûm 30/56.

50 el-Kehf 18/68.

${ }^{51}$ Aḥmed b. Mușțafâ el-Merāḡī, Tefsīru'l-Merāġī, 30 Cilt (Mısır: Şeriketü ve Mektebetü Mușțafā el-Bābī elHalebī ve Evlāduhū, 1365/1946), 16/7.
} 
değerlendirme aynı zamanda Cüşemīnnin de ișaret ettiği üzere ilahî sıfatlarla ilişkili olarak kıssanın, insan idrakini aşan yönüyle müteşâbih bir boyuta sahip olduğunu göstermektedir. Bu bakımdan müteşâbih kavramı çok farklı şekillerde tanımlansa $\mathrm{da}^{52}$ bunlar içerisinde en makul tanım Allah'ın sıfatları, cennet, cehennem gibi nesneler dünyasını aşan gaybî hakikatlerin beșer lisanı vasıtasıyla insan tarafından kavranabilecek bir düzeye indirgenmesidir. ${ }^{53}$ Dolayısıyla burada konuyu anlaşılır kılmak için aşkın varlıktan gelen bir bilgi akışına ihtiyaç bulunduğunu kabul etmekten başka bir seçenek yoktur. Taberînnin bu durumu Allah'ın kaza ve takdiri, Mâtürîdînnin ise Allah'ın kullarını sınaması, hayata ve ölüme hükmetme yetkisini elinde bulundurması açısından değerlendirmesinde de bu hakikatin tezahürünü görmek mümkündür. Ancak modern dönemde bu kıssanın şer'î, hukûkî, teşriî yönünün bulunmadığını açıkça ifade etmeleri açısından İbn Âşûr ve Mevdûdî’nin konuya daha bir netlik kazandırdıkları söylenebilir. Bununla birlikte geçmişte ve günümüzde pek çok müfessirin yaptığı gibi konunun hukûkî bir zeminde ele alınmaya çalıșılması meseleyi anlaşılır kılmaktan ziyade daha da çıkmaza sürüklemiştir.

Şu halde bu kıssa ile anlatılmak istenen nedir? Allah, neden buradaki mesajı başka bir anlatıyla değil de bir çocuğun öldürülmesi olayı üzerinden vermiştir? Bu sorunun cevabı kıssanın Kur'an'daki ayrıntılarında doğrudan verilmemiştir. Bununla birlikte Hz. Mûsâ'nın şahsında insanın sahip olduğu bilginin sınırlı olduğu, olayların görünen yüzünün her zaman hakikatini yansıtmayacağı ve daha bilgili insanların bulunabileceğinin hesaba katılması gerektiği mesajı iletilmek istenmiş olabilir. Bu noktada kıssada sıkça kullanılan "te'vîl” lafzı anahtar bir kavramdır. Şöyle ki gerek bu kıssada gerekse farklı ayetlerde tevil kavramı bir şeyin hakikatine, mahiyetine ve künhüne dair bilgi sahibi olmayı ifade etmektedir. ${ }^{54}$ Buna göre çocuğun öldürülmesi normatif düzeye indirgenmemesi gereken bir anlam boyutuna sahiptir. Yani burada varlığın ve hakikatin bilgisine dair insanın zihin dünyasında bir tasavvurun inşası hedeflenmiştir. Bu tasavvur, bir yönüyle insanın ve içinde bulunduğu varlık dünyasında sahip olduğu gerçeklik açısından hakikatle olan bağının sınırlı oluşuyla, diğer bir yönüyle ise bizzat hakikati temsil eden ve her şeyi kuşatan bir yaratıcının varlığıyla ilişkilidir. Nitekim Hızır’la Mûsâ buluştuklarında Hızır'ın "Sen asla benimle beraberliğe sabredemeyeceksin. Hakkında bilgi sahibi olmadığın bir şeye nasıl sabredesin ki?" ve ayrılmadan önce "Ben bunu kendi irademle yapmadım" şeklindeki sözleri bu tespiti teyit etmektedir.

$\mathrm{Bu}$ konuda daha ayrıntılı bilgi veren hadis rivayetlerinin Kur'an'ın özet olarak kaydettiği bu konuya açıklık getirdiği ve Kur'an'daki anlatıyı tamamlayıcı nitelikte olduğu görülür. Bu rivayetlerden birine göre, Hz. Mûsâ'ya insanların en bilgininin kim olduğu sorulduğunda kendisini öne sürmesi üzerine Allah'ın uyarı ve azarlamasına maruz kaldığı ve iki denizin birleştiği yerde ondan daha bilgili bir

52 bk. M. Sait Şimșek, Kur'an'ın Anlaşılmasında Íki Mesele (Konya: Kitap Dünyası, 2012), 19

${ }^{53}$ M. Hayri Kırbașoğlu, İslam'ın Kurucu Metni Kur'an Araștırmaları (Ankara: Otto Yayınları, 2015 ), 37.

54 bk. Yusuf Işıcık, Kur'an'ı Anlamada Temel Bir Problem Te'vîl (Konya: Esra Yayınları, 1997), 41-60; Abdulfettāḥ el-Hुālidī, et-Tefsīr ve't-te'vīl fi'l-Kur'ān (Ürdün: Dāru'n-Nefāis, 1996), 42-130. 
kulunun olduğu bildirilir. ${ }^{55}$ Bu rivayet olayın tarihsel arka planıyla ilişsili olsa da kıssanın Kur'an'a nasıl bir çerçevede konu olduğunu göstermesi açısından önemlidir. Buna ilave olarak, Țaberînnin kıssayı nüzul ortamını göz önünde bulundurarak, Müşriklerin sonlarının geleceğine ve Hz. Peygamber'in onların şiddet ve inkârlarına sabır göstermesi gerektiğine yönelik bir bağlamda izah etmesi dikkat çekicidir.

Öte yandan İlhami Güler tarafından yapılan bir çalışmada Kur'an'da HızırMûsâ kıssasında Hızır'ı âsi çocuğu öldürmesinin insandaki adalet duygusunu zedeleyeceği, Allah'ın mutlak âdil oluşuna gölge düşürebileceği ve kimileri için olumsuz bir örnek oluşturabileceği ileri sürülmüştür. Ona göre Hızır'ın bu eylemlerinde "Allah, 'kesinleşmemiş kader' gereği insanlarla ahlâkî ölçüler çerçevesinde ilişki kurmuştur." ${ }^{56} \mathrm{Bu}$ ifadeleriyle o, Hızır'ın anılan eylemini Allah'ın ahlak ve adalet ilkesiyle bağdaştıramadığını açıkça dile getirmiștir. Buna karşın, Kur'an'da yer alan Hz. İbrâhîm'in oğlunu kurban olarak kesmesini emretmesini, Allah ile insanlık arasındaki iliş̧kiye teşmil edilecek bir yanı bulunmadığı, bu emrin Hz. İbrâhîm'in sınanması amacıyla verildiği ve kesme olayının gerçekleşmediği gerekçesiyle bir sorun olarak görmemiştir. ${ }^{57} \mathrm{Ne}$ var ki yazarın Hz. İbrâhîm'in bu kıssasının Allah ile insanlık arasındaki ilişkiyle bir irtibatının bulunmadığını ifade etmesinin çok iddialı bir yaklaşım olduğunu kabul etmek gerekir. Zira bu kıssada yer alan temalardan da Allah-insan ilişkisi hakkında pekâlâ bazı sonuçlar çıkarmak mümkündür. Buna mukabil, onun bu mantık çizgisini Hızır-Mûsâ kıssasında sürdürmemesini temellendirmede geçerli bir argümana sahip olduğu söylenemez. Zira bu düşünceden hareket edilirse, Hz. İbrâhîm'in Allah'tan aldığı emirle çocuğunu kesmek için yüzükoyun yatırdığında onu kaybetme endişesinin doğurduğu psikolojik baskının ve oğlunun yaşadığı olağandışı bir ölümü tatma korkusunun ne tür bir adalet anlayışıyla izah edileceği merak konusu hâline gelir. Ayrıca bu tür durumlarda mağduriyetlerin adaletsizlik olarak tavsif edilmesindeki ölçütün olayın ölümle sonuçlanması olup olmadığı sorusu akla gelmektedir. Aslında Güler, Allah'a ait ahlâkî vasıfların kusursuz olmasına karşın, insandakilerin eksikliklerle dolu olabileceğini dile getirmesine ${ }^{58}$ rağmen insanın Allah'a ait bazı fiillerin başlangıçta insan tarafindan anlaşılamayacağı hususunu göz ardı etmiştir. Şüphesiz onun bu konudaki ahlakilik tanımlaması, kıssanın tarihi gerçekliğini kabul ettiğini gösterir. Aksi durumda o, Hz. İbrâhîm'e oğlunu kurban etmesinin emredilmesi hakkında nasıl bir itiraz ileri sürmediyse burada da bir sorun görmeyecekti. Buna rağmen yazar, herhangi bir eleştiri yöneltmeden bu kıssanın mitik bir anlatı ve Gılgamış Destanı'nın bir parçası olduğunu ileri süren Muhammed Arkoun'un (1928-2010) görüşlerini aktardıktan sonra herhangi bir değerlendirmeye yer vermeyerek böyle bir ihtimali gündeme getirmiş olmaktadır. ${ }^{59}$

Hemen ifade edelim ki Güler'i böyle bir değerlendirme yapmaya iten sebep-

\footnotetext{
55 bk. Buhārî, “İlim”, 3 (No. 74); Müslim, “Fezāil”, 46 (No. 2380).

56 bk. Güler, Allah'ın Ahlakiliği Sorunu, 105.

57 Güler, Allah'ın Ahlakiliği Sorunu, 74.

${ }^{58}$ Güler, Allah'ın Ahlakiliği Sorunu, 49-50.

${ }^{59}$ Güler, Allah'ın Ahlakiliği Sorunu, 105-106.
} 
lerden birisinin kıssadaki anlatıda Hızır'ın çocuğu öldürmesi üzerinde aşırı odaklanması ve konuyu kelâmî/hukûkî tartışmaların parçası hâline getirmesi, sonuçta olayın bütün olarak anlaşılmasına yardımcı olabilecek ayrıntıları göz ardı etmesi olduğu söylenebilir. Hal böyleyken o, sorunun kelamcılar tarafından Kur'an'a parçacı-lafızcı yaklaşılmasından kaynaklandığı tespitinde bulunur ve kendisinin konuyu bütünlükçü olarak ele almaya çalıștığını ileri sürer. ${ }^{60}$ Oysa ayette Hızır'ın Allah katından bilgelik ve özel bilgi verilen bir kul olduğundan söz edilmiştir. ${ }^{61}$ Buna ilave olarak, Hızır'ın Mûsâ ile buluşmalarında ona en başta "Sen benimle beraber olduğunda karşılaşacağın olaylara katlanamazsın. Zaten içyüzünü bilmediğin bir șeye nasıl katlanasın ki?"'62 ş̧eklinde Mûsâ'nın beşer aklının üstünde ve olağandışı olaylarla karşılaşacağı ve bunun Allah'ın iradesiyle gerçekleştiği bildirilmiştir. Kıssada vurgulanan bu ana mesajın yazar tarafından yeterince göz önünde bulundurulmaması nedeniyle, kendisinin bu hususta bütünlükçü bakışı pek de yakalayamadığı müşahede edilmektedir.

Söz konusu iddiada Allah-insan ilişsisinin ahlâkî bir temele oturduğu tezinden hareket edilmiştir. ${ }^{63}$ Doğrusu, Allah'ın insanla ilişkisinde "merhametli", "affeden", "zulmetmeyen" olması gibi birtakım ilkeleri elbette vardır. Ancak O'nun; ilim, irade ve kudretiyle tüm varlığı kuşatması itibarıyla esmâ ve sıfatlarının ne zaman ve ne şekilde tecelli edeceği insan açısından kimi zaman meçhul bir konudur. Buna mukabil yazar, insan idrakini așan konularda ahlâkî temelin ne olduğunu ve bunu kimin tespit edeceği hususunu gündemine almamıştır. Bundan dolayı Hızır'ın Allah'ın emriyle çocuğu öldürmesini O'nun adaletiyle uzlaștıramamıştır. Buna mukabil yazar, Allah ile insan arasındaki ilișkinin "kelime", "ahd" ve "mîsâk" kavramlarıyla sevgi, merhamet ve adalet ekseninde ahlâkî bir zemine dayandığını ileri sürmüştür. ${ }^{64}$ Böylece eleştiri konusu yaptığı Eş'ariyye'nin Allah'ın irade ve kudret sıfatlarına aşırı odaklanarak adalet ve hikmetini göz ardı etmesine benzer bir yanılgiya düşmüştür.

Bütün bu açılamalardan yola çıkarak kulun fiilleriyle Allah'ın fiillerinin sebep-sonuç, hüküm-değer açısından birbirinden ayırt edilmesinin zorunlu olduğu anlaşılmaktadır. Buradaki tartışmanın kadim köklerini Mu'tezile'nin “Allah'ın adaleti gereği aslah olanı kulları için yaratması vaciptir"65 şeklinde formüle ettiği düşüncede gözlemlemek mümkündür. Bu yaklaşım biçiminin Mâtürîdî tarafından "Allah Teâlâ hakîmdir. O'nun fiilleri hikmetin dışına çıkmaz" șeklindeki ifadelerle tenkit ve tadil edilmeye çalışıldığı görülür. Mâtürîdî’nin aslah ve hikmetli olanın ne olduğunu belirleme hakkının Allah'a ait olup, fiilin kendisinden anlaşılmayacağını belirtmesi, Mu'tezile'den ayrıştığı bir husustur. ${ }^{66}$ Yazar, Mu'tezile ve Mâtürîdî'nin

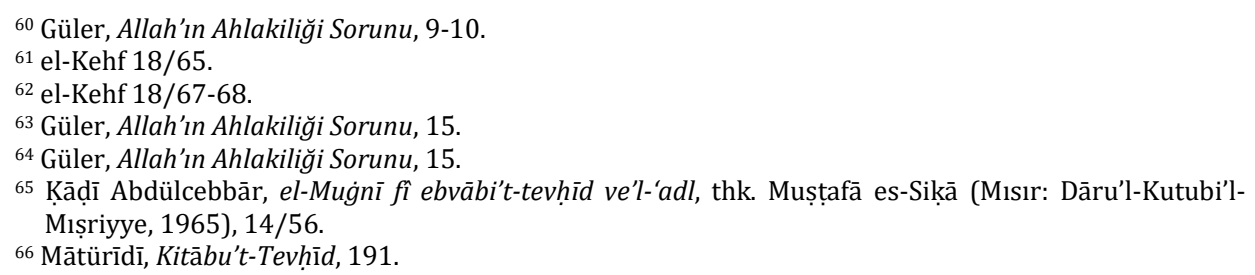


Allah'ın insanla ilişkili fiillerinde hikmet ve maslahata aykırı olmadığı konusundaki değerlendirmelerinden güç alırken bunun bazen ilk bakıșta anlaşılamamasının bir başka hikmet ve maslahata mebni olabileceği gerçeğini gözden kaçırmıştır. Kendisi Mâtürîdî'nin insan aklının her zaman Allah'ın fiillerindeki hikmet, adalet ve ihsanı anlayamayacağı, zira bilgisinin sınırlı ve duygularının etkisinde kaldığı biçiminde konunun özünü yansıtan açıklamalarını dikkate almamış gözükmektedir. ${ }^{67}$

Mâtürîdî’nin Allah'ın fiillerinde hikmetli olduğu ve aslah olanı belirleme güç ve yetkisini elinde tuttuğu yönündeki açıklamalarından destek alarak şunu söyleyebiliriz: Geçmişi ve geleceği, görünen ve görünmeyen âlemleri bilen Allah'ın Kur'an'da anlatıldığı üzere kâdir-i mutlak, alîm ve habîr oluşuna ircâ edilmesi gereken tasarrufları vardır. Bu tasarrufların insandaki adalet duygusunu bozacak, hayatı yaşanmaz kılacak tasarruflar olduğunu söylemek Kur'an'da ortaya konulan Allah tasavvuruyla kesinlikle bağdaşmaz. Bu kıssada anlatılan olayların -dünya düzleminde gerçekleşse de- hukûkî ve kelâmî bir tartışmaya konu olabilecek evsafta olmadığı ortadadır. Zira bu kıssadaki olayların fizik âleme konu olan ve görünen yüzünden (zâhir) ziyade olayların beşerî bir akılla çözülemeyecek mahiyette geleceğe (gayb) dair öngörüde bulunmayı içerdiği müşahede edilir. Yoksa burada söz konusu edilen temanın dünyevî hukukla ve insandaki adalet idesiyle telif edilmesine imkân bulunmamaktadır.

Doğrusunu söylemek gerekirse, kıssada Hızır’ı çocuğu öldürmesi bağlamında, eylemin haklılığını ispatlamak üzere, kimi tefsirlerde çocuk hakkında âsî, yol kesen, kâfir, haydut olduğu şeklindeki nitelemelerin kıssa hakkında olumsuz algıları beslediği/besleyeceği söylenebilir. Oysa Mâtürîdî’nin de dediği üzere, çocuğun öldürülme sebebini bilmemiz gerekmediği gibi, bu tür açıklamalar ikna edici olmaktan uzaktır. Zira çocuğun öldürülmesi Allah'ın emriyle gerçekleştirilmiştir. Bir kulunun ister ölüm meleğine, isterse bir başka kuluna emredilerek hayatına son verilmesi Allah'ın yetkisindedir. ${ }^{68}$

Buna mukabil Eş‘arîlikte Allah'ın ahirette küçük çocuklara ve müminlere azap edip kâfirleri cennetine koyması hâlinde bile bunun O'nun adaletine zarar vermeyeceği ileri sürülmüştür. Ancak bu düşüncede olanlara göre, Allah bunu yapmayacaktır. Çünkü Allah, müminlere değil kâfirlere azap edeceğini bildirmiştir. ${ }^{69} \mathrm{Ne}$ var ki bu düşüncenin Hızır'ın çocuğu öldürmesine meşruiyet kazandırılabileceğini varsaymak makul gözükmemektedir. Zira bu açıklamada Allah'ın kudret ve iradesine gereğinden fazla vurgu yapılması, O'nun bu olumsuz fiilleri hikmet ve adaleti gereği yapmayacağ gerçeğinin göz ardı edilmesi sonucunu doğurmuştur. Ayrıca Eş'arînnin (ö. 324/935-36) sözünü ettiği konu, Kur'an'ın ana temalarından olan uhrevî hayatta herkese amellerinin karşılığının verileceği ilkesiyle ilgilidir. Oysa Hızır'ın çocuğu öldürmesinin bu konuyla bir ilişkisinin olduğunu söylemek pek mümkün değildir. Dolayısıyla, beşer ufkunu aşan dikey düzlemdeki bir olayı

\footnotetext{
${ }^{67}$ Güler, Allah'ın Ahlakiliği Sorunu, 56-57.

${ }^{68}$ Mātürīdī, Te'vīlātül-Kur'ān, 7/200.

${ }^{69}$ Ebü'l-Hasen el-Eș'arī, Kitābu'l-lum'a fi'r-reddi 'alā ehli'z-zeyg் ve'l-bida', tsh. Hamūde Ġarābe (Mısır: Matba'atü Mısır, 1955), 116-117.
} 
beșerî hayatı düzenlemeye matuf hukûkî/ahlâkî ilkelerden hareketle açıklamak her şeyden önce mantıkî tutarlılıktan yoksundur. Eş'arîlik'teki bu yaklaşım biçiminin müfessirlerin konuyu hukûkî çerçevede izah etmelerine etki eden faktörlerden birisi olduğu düşünülebilir.

Öte yandan, buradaki en temel yanılgı, Hz. İbrâhîm'e oğlunu kurban etmesinin emredilmesindekine benzer biçimde Hızır-Mûsâ kıssasında da beşer üstü temaların bulunduğu gerçeğinin dikkatlerden uzak tutulmasıdır. Kur'an'da bu tür beșer üstü temaların bulunmasıyla insanoğluna her șeyden önce varlık hakkında sınırlı bilgiye sahip olduğu bilincinin kazandırılması hedeflenir. Bu sayede insan şerî̀ ahkâmın hikmetlerini kavramada da kuşatıcllık iddiasından kurtulur ve idrak sınırlarının ötesinde de bilgilerin bulunduğu ona hatırlatılmış olur. Nitekim Kur'an'da melek, cennet, cehennem, ahiret, hesap, sırat, mizan vb. gaybî konularda olduğu gibi, fizik yasalarına göre mahiyet sorușturmasına konu edilemeyen, bu konudaki tasvirlerin de meseleyi beșer idrakine indirme amacına bağlı olduğu pek çok kavram vardır. Binaenaleyh kıssada yer alan ve beşer aklıyla uzlaştırılmayacak evsaftaki olaylardan çocuğun öldürülmesiyle onun bir kazada ölmesi arasında ilahî iradenin belirleyici karakteri açısından bir fark yoktur. Bu tür olayların ardındaki hikmetin anlaşılması kadar anlaşılmama ihtimali de vardır. Yoksa Mevdûdînnin de dediği gibi insanın yaratılışından beri var olan hiçbir kanun başkasının malına zarar vermeye ve masum bir insanın öldürülmesine izin vermemiștir. ${ }^{70}$ Kur'an'ın genel muhtevası dikkate alındığında özellikle modern akılla izah edilmesi zor olan hususların Hızır-Mûsâ kıssasına has olmadığı görülür. Örneğin meleklerin sihir öğretmeleri, ${ }^{71} \mathrm{~Hz}$. Süleymân'ın Sebe kraliçesini inanmaya mecbur etmesi, ${ }^{72}$ Ashâb-1 Kehf'in mağarada uykuya daldıktan yaklaşık üç asır sonra uyanmass ${ }^{73}$ vb. kıssalarda da benzeri bir durumu müşahede etmek mümkündür. Dolayısıyla Hızır ve Mûsâ hadisesinde olduğu gibi bütün bu anlatılarda insanın varlıkla ve hakikatle olan ilişkisinin varoluşsal imkânlarına ve sınırlılıklarına yönelik bir bilinç ve tasavvur oluş̧turulmaya çalışılmıștır. Kư'an'a konu olması itibariyle bu olayı, salt hukûkî bir zemine indirgemek ya da kelâmî bir tartışmaya dönüștürmek yerine, çok daha esaslı, etkileyici ve kuşatıcı olması açısından varlığa dair bir bilincin inşası bağlamında düşünmek daha isabetlidir.

Öte yandan bilginin zâhir ve bâtın şeklindeki tasnifinin tasavvuf geleneğinde nübüvvet ve velâyet kavramlarıyla eşleştirildiği ve bu eşleştirmede Hızır-Mûsâ kıssasının model alındığı müşahede edilmektedir. ${ }^{74}$ Ne var ki bâtın ilminin üstünlüğünün temel alındığı bu yaklaşımda velinin nebiye üstün olduğu şeklindeki çıkarımın önünün nasıl alınacağı çözümsüz kalmıştır. Tıpkı meleklerin sihir öğretmekle derece kaybına uğramayacakları gibi Hızır’a Hz. Mûsâ'nın muttali olmadığı tür-

\footnotetext{
${ }^{70}$ Mevdūdī, Tefhīmu'l-Kur'ān, 3/171.

71 el-Bakara 2/102.

72 en-Neml 27/28-31.

73 el-Kehf $18 / 25$.

74 Örneğin bk. Necmeddin Bardakçı, Hakikatin Keşfi-Hz. Musa ve Hızır (İstanbul: Rağbet Yayınları, 2. Basım, 2019), 13.
} 
den bilgilerin verilmesi onu daha üstün kılmaz. Zira ne Hızır ne de melekler söz konusu eylemlerinde kendiliklerinden hareket etmiş değillerdir. Onlar bu eylemlerdeki sembolik anlatımın altında yatan mesajın iletilmesinde birer vasitadan ibarettirler. Bu bağlamda Hızır'ın tüm bu eylemleri peygamber kimliğiyle Allah'tan aldığı vahye dayanarak ortaya koyduğu, konuyla ilgili sergilenen yaklaşımlar arasindadır. ${ }^{75}$

\section{Sonuç}

Allah'ın insan hayatını ilgilendiren fiillerinin beșeri adalet tasavvuruna göre izah edilmesi her zaman imkân dâhilinde değildir. Allah'ın âdil oluşunun apriori olarak kabulü ile tikel hükümlerde bu ilkelerin varlığına zihin faaliyeti sonucunda ikna olunması birbirinden farklı durumlara işaret eder. Nitekim insana doğuştan verilen cinsiyet, zekâ, güzellik, zenginlik gibi konulardaki farklılıklar kişilerde bazen adaletsizlik algısı oluşturabilir. Kur'an'da öngörülen bakış açısına göre dünya hayatının imtihan yeri olmasına ve Allah'ın her fiilinde insanın bilemediği hikmetler bulunduğuna inanılması mevcut durumu kabullenmeye yardımcı olur. Zira ilahî vahyin insandaki algı, tasavvur ve bakış açılarını tashih ve tadil etme görevi bulunmaktadır. Bu durum, Kur'an'da anlatılan Hızır-Mûsâ kıssasında Hızır'ın âsi çocuğu öldürme olayı hakkında da geçerliliğini korumaktadır. Bu kıssada, Hızır'ın çocuğu öldürme meselesinin kimi modern algı ve tasavvurlara göre sağlıklı bir zeminde ele alınamadığı, bu muvacehede Allah'ın adaleti hakkında kuşku uyandıran değerlendirmelerde bulunulduğu görülür. Kıssadaki anlatıda dünyada karşılaştığımız, ama nedenini bilemediğimiz bazı olumsuzlukların Allah'ın ezelî ilminde bir anlam ve değerinin bulunduğu somut örnekler üzerinden dile getirilir. Bu kıssadan ilk bakışta olayların görünen cephesinin ardında insanın göremediği ve bilemediği bir yön bulunabileceği mesajı verilmektedir. Bu da, insanı kendi sınırlarına çekme ve merkezde Allah'ın bulunduğu gerçeğini hatırlatma işlevi görür. Nüzul döneminde de bu kıssa aracılığıyla Hz. Peygamber'e insanın hakikati kuşatamayacağı mesajının verildiği yönündeki bir kısım müfessirlerce yapılan değerlendirmeler bu tespiti desteklemektedir. Konuyla ilgili rivayetler de bu kıssanın doğru okunmasına katkı sağlamaktadır.

Author Contributions / Yazarların Katkısı: The contribution rate at all stages of the article is fifty percent for the corresponding author and also fifty percent for the second author. / Makalenin tüm aşamalarında birinci ve sorumlu yazarın katkı oranı yüzde elli, ikinci yazarın katkı oranı yüzde ellidir.

Funding / Finansman: This research received no external funding. / Bu araştırma herhangi bir dış fon almamıştır.

Conflicts of Interest / Çıkar Çatışması: The author declare no conflict of interest. / Yazar, herhangi bir çıkar çatışması olmadığını beyan eder.

${ }^{75}$ Mātürīdī, Te'vīlātül-Kur'ān, 7/195. 


\section{Kaynakça}

Bardakçı, Necmeddin. Hakikatin Keșfi-Hz. Musa ve Hızır. İstanbul: Rağbet Yayınları, 2. Basım, 2019.

Buhāāī, Ebū Abdillāh Muḥammed b. İsmāīl. el-Cāmi'u'ṣ-ṣaḥịh. nşr. Muḥammed Züheyr b. Nașr. 9 Cilt. b.y.: Dāru Tavkịi'n-Necāt, 1422/2001.

Cüşemī, Ebū Sa'd Muḥsin b. Muḥammed Ḥākim. et-Tehżīb fi't-Tefsīr. thk. Abdurraḥmān b. Süleymān es-Sālimī. 10 Cilt. Kahire: Dāru'l-Kutubi'l-Mıșrī, ts.

Çalışkan, Necmettin. "Kehf Sûresi Bağlamında Hz. Mûsâ ve Sâlih Kul (Hızır) Kıssası ve Antakya'da Hızır İnancının Sosyo-Kültürel Etkileri”. Toplum Bilimleri Dergisi 9/18 (2015), 243-262.

Eş'arī, Ebü'l-Ḥasen. Kitābu'l-lum'a fi'r-reddi 'alā ehli'z-zeyg் ve'l-bida'. tsh. Hamūde Ġarābe. Mısır: Matba'atü Mısır, 1955.

Fahruddīn er-Rāzī, Ebū Abdullāh Muhammed b. Ömer. Mefātīḥu'l-ġayb. 32 Cilt. Beyrut: Dāru İhyāi't-Türāsi'l-'Arabī, 1999.

Güler, İlhami. Allah'ın Ahlakiliği Sorunu. Ankara: Ankara Okulu Yayınları, 2019.

Hālidī, Abdulfettāḥ. et-Tefsīr ve't-te'vīl fi'l-Kur'ān. Ürdün: Dāru'n-Nefāis, 1996.

Işıcık, Yusuf. Kur'an'ı Anlamada Temel Bir Problem Te'vîl. Konya: Esra Yayınları, 1997.

İbn Āşūr, Muhammed et-Ṭāhir b. Muhammed. et-Tahrī̄r ve't-tenvīr. 30 Cilt. Tunus: Dāru'lTūnisiyye, 1984.

İbn Aṭiyye, Ebū Muhammed Abdülḥaḳ b. Gālib. el-Muḥarrerü'l-vecīz. thk. Abdüsselām Abduşşāfi' Muhammed. 6 Cilt. Beyrut: Dāru'l-Kutubi'l-İlmiyye, 1422/2001.

İbn Ebī Ḥātim, Ebū Muḥammed Abdurrahmān b. Aḥmed er-Rāzī. Tefsīru İbn Ebī Hātim. thk. Esad Muhammed et-Ṭayyib. 10 Cilt. Suudi Arabistan: Mektebetü Nizār Mușțafā elBāz, 1419/1998.

Kạậi Abdülcebbār. el-Muginī fĩ ebvābi't-tevḥīd ve'l-'adl. thk. Mușțafā es-Sikāā. 20 Cilt. Mısır: Dāru'l-Kutubi'l-Mıșriyye, 1965.

Kāậi Abdülcebbār. Şerḥu Ușūli'l-Ḩamse. çev. İlyas Çelebi. 2 Cilt. İstanbul: Türkiye Yazma Eserler Kurulu Başkanlığı, 2013.

Kerecī, Ebū Ahmed. Nüketüll-Kur'āni'd-dālle 'ale'l-beyān fĩ envā't'l-ulūm ve'l-aḥkām. thk. İbrāhīm b. Manșūr el-Cüneydil. 4 Cilt. b.y.: Dāru'l-Ḳayyim, 1424/2003.

Kırbaşoğlu, M. Hayri. İslam'ın Kurucu Metni Kur'an Araştırmaları. Ankara: Otto Yayınları, 2015.

Kurtubī, Ebū Abdullāh Muhammed b. Ahmed. el-Cāmi' li aḥkāmi'l-Ḳur'ān. thk. Aḥmed Berdūnī. 20 Cilt. Kahire: Dāru'l-Kutubi'l-Mıșrıyye, 1964.

Maḥmūd Mağribī, İman bint Abdurraḥmān. "Hz. Musa ve Hızır (as) Kıssası: İsrâîliyyât Rivâyetlerine Karşı Eleştirel Bir Yaklaşım”. çev. Mustafa Şentürk. Amasya Üniversitesi İlahiyat Fakültesi Dergisi 5 (2015), 173-208.

Mātürīdī, Ebū Manșūr. Kitābü't-Tevhīid. thk. Bekir Topaloğlu - Muhammed Aruçi. İstanbul: İrşad Kitabevi, 1422/2001.

Mātürīdī, Ebū Manșūr. Te'vīlātü'l-Kur'ān. thk. Murat Sülün. 17 Cilt. İstanbul: Dāru'l-Mīzān, 2018.

Mavil, Kılıç Aslan. "Hızır-Mûsâ Kıssasında Kader - Çift Perspektifli Bir Bakış -“. İnsan ve Toplum Bilimleri Araștırmaları Dergisi 5/8 (2016), 2496-2516.

Merāgìì, Aḥmed b. Mușțafā. Tefsīru'l-Merāgìi. 30 Cilt. Mısır: Şeriketü ve Mektebetü Mușțafā elBābī el-Ḥalebī ve Evlāduhū, 1365/1946.

Meral, Yasin. "Mûsâ-Hızır Kıssası ve Kıssasının Yahudi Kökeniyle İlgili İddialarının Değerlendirilmesi". Ankara Üniversitesi İlahiyat Fakültesi Dergisi 55/2 (2014), 129150.

Mevdūdī. Tefhīmu'l-Kur'ān. çev. Muhammed Han Kayani vd. 7 Cilt. İstanbul: İnsan Yayınları, 2005.

Muḳātil b. Süleymān, Ebü'l-Ḥasen b. Beşīr el-Ezdī el-Belḩī. Tefsīru Mukāatil. thk. Abdullāh Maḥmūd Şeḥhāte. 5 Cilt. Beyrut: Dāru İhyāi't-Türās, 1979. 
Muțahhari, Murteza. Adl-i İlāhî. çev. Hüseyin Hatemî. İstanbul: Kevser Yayınları, 2. Basım, 2014.

Müslim, Ebü'l-Hüseyn. el-Ḥaccāc. el-Câm'u'ṣ-ṣaḥịh. nşr. Muhammed Fuād Abdülbāḳī. 5 Cilt. Kahire: y.y., 1374-75/1955-56.

Oral, Osman. "Kelam İlminde İlahi Adalet". Kelam Araştırmaları Dergisi [Kader] 11/1 (2013), 443-457.

Öztürk, Mustafa. "Bilge Kul-Musa Kıssası ve İslam Kültüründe Hızır Mitosu”. Ondokuz Mayıs Üniversitesi İlahiyat Fakültesi Dergisi 14/15 (2003), 245-281.

Șābūnî, Nūruddîn. el-Bidāye fî ușūli'd-Dîn. thk. Bekir Topaloğlu. İstanbul: İfav Yayınları, 11. Basım, 2013.

Semerḳandī, Ebü'l-Leyś. Bahru'l-'ulūm. 3 Cilt. b.y.: y.y., ts.

Șāfiī, Muhammed b. İdrīs. Müsned. nșr. Yūsuf Ali ez-Zevāvī - İzzet el-Atțār. 2 Cilt. Beyrut: Dāru'l-Kutubi'l-İlmiyye, 1370/1951.

Șevkānī, Muhammed b. Ali b. Muhammed. Fethu'l-kadīr. 6 Cilt. Beyrut: Dāru İbn Kesīr, 1993.

Şimşek, M. Sait. Kur'an'ın Anlaşılmasında İki Mesele. Konya: Kitap Dünyası, 2012.

Taberī, Muhammed b. Cerīr Ebū Ca'fer. Cāmi'u'l-beyān fi te'vīli'l'l-Kur'ān. thk. Ahmed Muhammed Şākir. 24 Cilt. Beyrut: Müessesetü'r-Risāle, 2000.

Zeccāc, Ebū İshāk İbrāhīm b. es-Serī b. Sehl. Me'āni'l-Kur'ān ve i'rābüh. 5 Cilt. Beyrut: Ālemü'l-Kütüb, 1408/1988.

Zemahșerī, Ebü'l-Kāsım Maḥmūd b. 'Amr Cārullāh. el-Keșşāf 'an hakạāikıı ġavāmızi't-tenzīl. 4 Cilt. Beyrut: Dāru'l-Kutubi'l-Arabiyye, 1988. 